\title{
ВІЙСЬКОВА ЕПІДЕМІОЛОГІЯ З ЕПІДЕМІОЛОГІЕЮ НАДЗВИЧАЙНИХ СИТУАЦІЙ : ПІДРУЧНИК / М. А. АНДРЕЙЧИН, О. Д. КРУШЕЛЬНИЦЬКИЙ, В. С. КОПЧА, I. В. ОГОРОДНІЙчУК ; за ред. М. А. Андрейчина. - Тернопіль : ТДМУ, 2015. - 320 с.
}

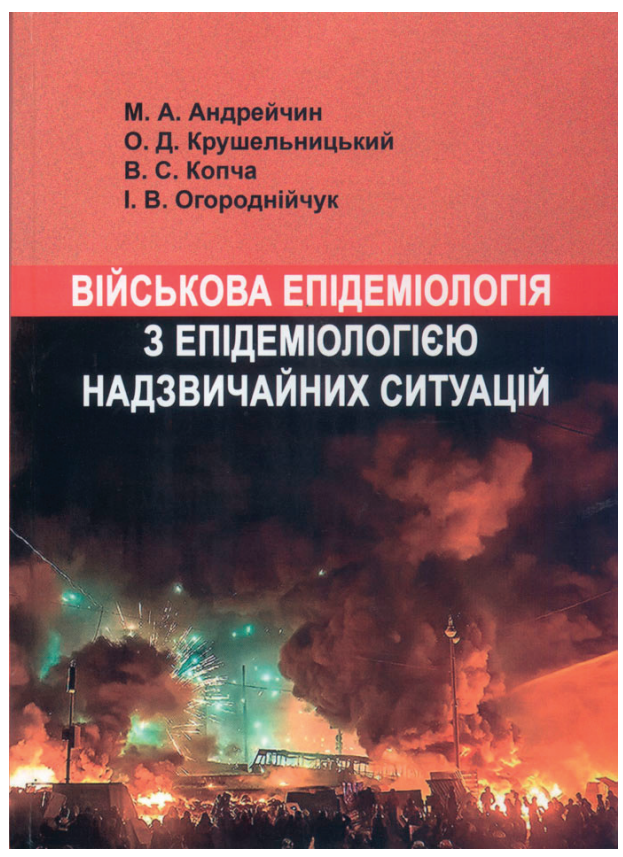

Військовий колектив й умови військової праці вирізняються особливостями, що диктують необхідність розробки і здійснення спеціальних заходів для протиепідемічного захисту військ у мирний і воєнний час. Такі заходи мають винятково важливе значення для боєздатності війська, тому що втрати від інфекційних хвороб за певних умов можуть багаторазово перевищувати інші санітарні втрати. Крім того, епідеміологічне неблагополуччя у військах може зумовити розвиток епідемії серед цивільного населення.

Військова епідеміологія сорормувалася на стику епідеміології та військової медицини. Опираючись на наукові досягнення, ця дисципліна, своєю чергою, збагачує епідеміологію новими організаційними формами роботи. Водночас військова епідеміологія нерозривно пов'язана 3 іншими військовими дисциплінами, зокрема з організацією і тактикою медичної служби, військово-польовою терапією, військово-польовою хірургією, військово-медичним постачанням тощо.
У разі виникнення природних і техногенних катастрофр будуть потрібні значні людські сили й засоби. Тому в ліквідації природних і соціальних катаклізмів провідна роль належить війську, що діє у тісній співпраці з цивільними формуваннями.

Підготовка лікарів з питань епідеміології екстремальних умов, безумовно, $є$ нагальною потребою сьогодення. Але в Україні університетського підручника для цього донедавна не було. Перший підручник для студентів вищих медичних навчальних закладів III-IV рівнів акредитації, виданий 2002 року, був покликаний систематизувати навчальний матеріал з епідеміології екстремальних умов і військової епідеміології.

Готуючи новий підручник, автори доклали значних зусиль, щоб уникнути положень і тверджень, що за останні роки втратили актуальність, і суттєво доповнили текст матеріалами, які враховують найновіші досягнення науки та зміни, що за останні 30 років відбулись у Збройних Силах України у зв'язку з їх розбудовою й спробою перевести на профресійну основу.

Це спільна праця співробітників кафредри інфекційних хвороб та епідеміології Тернопільського державного медичного університету ім. І.Я. Горбачевського і касредри військово-профрілактичної медицини Української військовомедичної академії, що мають власний багаторічний досвід викладання вказаних предметів. Крім цього, у книзі узагальнено дані сучасних вітчизняних і закордонних авторів. Підручник складається з п'яти розділів.

У першому розділі, «Військова епідеміологія з епідеміологією надзвичайних ситуацій - розділ епідеміології та галузь військової медицини», розкрито значення військової епідеміології, ії основні підрозділи та завдання. Привертають увагу досі маловідомі для широкого загалу відомості про вітчизняну військову епідеміологію, елементи якої були започатковані ще у Запорізькій Січі. Незважаючи на відчутну нестачу інорормації, у підручнику вперше розкрито особливості протиепідемічного забезпечення в Армії Української Народної Республіки та Українській Повстанській Армії. У цьому ж розділі описано теперішню структуру са- 
нітарно-епідеміологічної служби Збройних Сил України, що дає змогу читачеві орієнтуватися у специфічних термінах і поняттях, якими насичена наступна частина книги.

У другому розділі, «Особливості розвитку епідемічного процесу серед особового складу військ і населення в мирний та воєнний час, а також при надзвичайних станах (ситуаціях)», досить повно описано структуру інфекційної захворюваності у воєнний час, особливо після застосування противником зброї масового ураження та під час інших екстремальних ситуацій. Вказано шляхи заносу інфекцій на театр воєнних дій і виносу з фрронту в тил країни. Розглянуто вплив району розташування військ на інсрекційну захворюваність особового складу, внутрішні чинники розвитку епідемічного процесу у військах, втрати від інфекційних захворювань і фрактори, які впливають на них при використанні зброї масового ураження та під час надзвичайних станів.

У третьому і четвертому розділах розглянуто організацію протиепідемічних заходів у військах і серед населення в надзвичайних ситуаціях і під час бойових дій, а також із сучасних позицій розглянуто характеристику та бойові властивості біологічної зброї. Тут обговорюються шляхи ліквідації епідемічних наслідків стихійних лих; описано роботу спеціалізованих фрормувань протиепідемічного захисту, а також закладів охорони здоров'я при виникненні епідемічних осередків; розкрито організацію протиепідемічного забезпечення військ при надзвичайних ситуаціях і у воєнний час; управління протиепідемічними заходами під час надзвичайних ситуацій; заходи, спрямовані на боротьбу 3 інфекційними хворобами і ліквідацію епідемічних осередків у військах. Не менш повно висвітлюються принципи санітарно-епідеміологічного забезпечення Збройних Сил України, організація протиепідемічного забезпечення залежно від умов і характеру бойової діяльності військ, прин- ципи використання підрозділів санітарно-епідеміологічних закладів за різних видів бойової діяльності військ, лікувально-евакуаційне забезпечення в умовах застосування противником біологічної зброї, а також організація медичної допомоги інфекційним хворим у діючій армії.

В останньому, п'ятому, розділі, «Основи організації біологічної розвідки та індикації біологічних засобів», розкрито неспецифічну та специфрічну індикацію біологічних середників, технічні засоби мікробіологічного аналізу, описано роботу лабораторій, розгорнутих з цією метою. Значну увагу приділено відбору проб, порядку їх доставки в лабораторію. Крім цього, пропонується порядок проведення тренувальних занять із специфрічної індикації біологічних засобів у санітарно-епідеміологічних закладах.

У кінці кожного розділу наведено контрольні запитання і завдання. Безперечно доцільними $є$ додатки, в яких наведено ряд фрорм професійної документації, витяг 3 рекомендацій ВООз «Першочергові дії в надзвичайних ситуаціях», захисний одяг, інкубаційний період при деяких інфекційних хворобах, схеми неспецифрічної і спеціальної екстреної профрілактики, розрахунок можливої інфрекційної захворюваності в районах стихійних лих, список рекомендованої літератури для глибшого опанування предметом.

Таким чином, у рецензованому підручнику, виданому за редакцією члена-кореспондента НАМН України, заслуженого діяча науки і техніки України, профресора М.А. Андрейчина, на сучасному рівні викладено основні положення військової епідеміології та епідеміології при надзвичайних станах. Він написаний відповідно до програми, затвердженої Міністерством охорони здоров'я, і може рекомендуватися для студентів вищих медичних закладів освіти України III-IV рівнів акредитації. Підручник дасть змогу підвищити якість підготовки студентів-медиків університетів і академій, а також лікарів на етапі післядипломної освіти.

Начальник кафредри організації медичного забезпечення Збройних сил Української військово-медичної академії, доктор мед. наук, профресор м.І. Бадюк (м. Київ).

Отримано 2.02.2016 р. 